\title{
Analysis of cutaneous adverse drug reactions in a tertiary care hospital in South Tamil Nadu
}

\author{
Aravind Baskar Murthy ${ }^{1}$, Amuthavalli K. ${ }^{2}$, Nirmaladevi P. ${ }^{3 *}$, Meenakshi B. ${ }^{4}$
}

\begin{abstract}
${ }^{1}$ Assistant surgeon, MD (DVL), Thiruthuraipoondi Government hospital, Tiruvarur, Tamil Nadu, India
${ }^{2}$ Assistant surgeon, MD (DVL), Sankari Government hospital, Salem, Tamil Nadu, India

${ }^{3}$ Department of Dermatology, Venereology and Leprosy, Tirunelveli medical college, Tirunelveli, Tamil Nadu, India

${ }^{4}$ Department of Pharmacology, Government Thoothukudi medical college, Thoothukudi, Tamil Nadu, India
\end{abstract}

Received: 24 November 2021

Revised: 22 December 2021

Accepted: 23 December 2021

\section{*Correspondence:}

Dr. Nirmaladevi P.,

Email: nirmaladevipalanivel@gmail.com

Copyright: (c) the author(s), publisher and licensee Medip Academy. This is an open-access article distributed under the terms of the Creative Commons Attribution Non-Commercial License, which permits unrestricted non-commercial use, distribution, and reproduction in any medium, provided the original work is properly cited.

\begin{abstract}
Background: Cutaneous adverse drug reactions (CADRs) are among the most frequently reported adverse drug reactions (10 to 30\%) with overall incidence of 6.2/1000 cases in India and 8\% of hospitalisation among Dermatology inpatients. The aim was to analyse the CADRs with reference to its prevalence, causative drugs, morphological patterns, polypharmacy and drug reaction severity by Hartwig's severity assessment scale.

Methods: This study was a retrospective study done in the Department of Dermatology, Venereology and Leprosy (DVL) over a period of 5 years (2015 to 2019) from CADR registers. Mean, standard deviation and chi square test were used for statistical analysis. $\mathrm{P} \leq 0.05$ was considered as statistically significant.

Results: A total of 134 cases of CADRs were encountered which comprised $0.2 \%(2 / 1000)$ of total OP census with equal gender ratio and involved most commonly the younger adults. The drug groups mainly responsible were anticonvulsants $(24.7 \%)$ followed by non-steroidal anti-inflammatory drugs (NSAIDS) (22.5\%), antibiotics (20.9\%) followed by antiretrovirals (ART) and antituberculous drugs (ATT). The common morphological patterns were acute exanthem (32.2\%), exfoliative dermatitis $(14.9 \%)$ and toxic epidermal necrolysis $(14.2 \%)$. Over the counter drugs accounted for $25.6 \%$ of cases. Around $38.1 \%$ were on polypharmacy. In this study, $15.7 \%$ had mild CADR, $53.7 \%$ had moderate and $30.6 \%$ had severe drug reactions with $2.2 \%$ mortality based on the Hartwig's severity assessment scale. Commonest cause of severe CADRs was anticonvulsants and benign CADRs was NSAIDS.

Conclusions: Proper history taking and documentation of data, recollection of sequence of events by the patient and drug re-challenge will help us in deciding the causative drug preventing further occurrence.
\end{abstract}

Keywords: Cutaneous adverse drug reactions, Drug allergy, Pharmacovigilance, Drug severity

\section{INTRODUCTION}

The definition of adverse drug reactions (ADR), as given by World Health Organization (WHO), is 'any response to a drug which is noxious and unintended and which occurs at doses, normally used for prophylaxis or diagnosis or therapy or disease or for modification of physiological function'. It excludes supratherapeutic doses, drug abuse and treatment failure and errors, which occurs while the drug is administered. ${ }^{1}$ Among ADRs, cutaneous adverse drug reactions (CADRs) are most frequently reported, comprising $10-30 \%$, which is $8 \%$ of hospitalisation among Dermatology inpatients in India and $2-3 \%$ at global level. ${ }^{2,3}$ The incidence of CADRs differs in different regions and ethnic groups. ${ }^{4-6}$ 
The drug reactions can be classified into benign and severe CADRs. Approximately $2 \%$ of all drug-induced skin reactions are considered "serious" according to WHO definition. $^{7}$ The world health organization (WHO) initiated a programme called pharmacovigilance programme (PvP) for reporting all adverse reactions produced by drugs in response to the thalidomide disaster detected in 1961. The Pharmacovigilance Programme of India (PvPI) was started by the Government of India on July $14,2010 .^{8}$

Reporting of ADRs and reviewing them is of paramount importance as it helps to predict the frequency of occurrence of drug reaction to specific drugs and susceptibility and patterns of manifestation in the population studied.

\section{METHODS}

This study was a retrospective study done in the Department of Dermatology, Venereology and Leprosy (DVL) in a tertiary care teaching institution over a period of 5 years (January 2015 to December 2019) including both outpatient (OP) and inpatient (IP) data from CADR registers, under Pharmacovigilance Programme of India, which also included follow up data. After obtaining clearance from Institutional Ethics committee (IEC), data were collected from predesigned proforma containing detailed history including duration of symptoms, list of drugs taken, reason(s) for drug intake and clinical examination details. Apart from demographic details, various parameters like prevalence in relation to causative drugs and morphological patterns, requirement of hospital stay, chronological order and sequence of clinical events with drug intake were evaluated. Severity of drug reaction was assessed by Hartwig's severity assessment scale which divided it into three categories and seven levels. This classification is based on factors like requirement of treatment change, withdrawal of drug, need of antidote, prolonged hospital stay, complications and death of the patient. $^{9}$ The benign CADRs include drug induced exanthem, pruritus, SDRIFE, urticaria, angioedema, anaphylaxis, serum sickness like reaction, lichenoid drug reaction, FDE, pityriasis rosea like eruption, erythema nodosum, acneiform eruptions. The severe CADRs which are associated with significant morbidity and mortality, include AGEP, DRESS/DHS, exfoliative dermatitis, SJS/TEN and generalised bullous FDE. ${ }^{10}$ Seriousness of reaction were categorized according to United States Food and Drug Administration criteria. ADRs not coming under serious ADRs were categorized as "Not Serious" ADRs. ${ }^{11}$ The data were compiled and analysed to determine the prevalence of CADR, morphological patterns, offending drugs and the nature and severity of CADR. Data were entered in MS Excel and analysed by SPSS. Numerical data were represented in mean and standard deviation for continuous variables and in proportion and percentage for categorical variables. For comparison of data, chi square test was used considering $\mathrm{p} \leq 0.05$ as statistically significant.

\section{RESULTS}

A total of 64,031 new patients had attended OPD during the study period, of which 134 cases of CADRs were recorded that comprised $0.2 \%$ of total OP census on average, with equal gender (M: F) ratio (67 each) and mean age of 37.9 years \pm 16.2 (range: 3 years to 77 years).

Table 1: Classification of CADRs with gender-wise distribution of various causative drug groups.

\begin{tabular}{|llllllll|}
\hline Drug group & Benign CADR & M & F & Severe CADR & M & F & Total $(\%)$ \\
\hline NSAIDS & 18 & 6 & 12 & 12 & 7 & 5 & $30(22.5)$ \\
\hline Anticonvulsants & 16 & 6 & 10 & 17 & 12 & 5 & $33(24.7)$ \\
\hline Antibiotics & 16 & 10 & 6 & 12 & 8 & 4 & $28(20.9)$ \\
\hline ART & 15 & 7 & 8 & 2 & 1 & 1 & $17(12.7)$ \\
\hline ATT & 7 & 6 & 1 & 2 & 0 & 2 & $9(6.7)$ \\
\hline Native medicines & 3 & 0 & 3 & 5 & 2 & 3 & $8(5.9)$ \\
\hline Antifungal & 3 & 2 & 1 & 1 & 0 & 1 & $4(3)$ \\
\hline Antihistamines & 2 & 0 & 2 & 0 & 0 & 0 & $2(1.5)$ \\
\hline Anihypertensives & 1 & 0 & 1 & 0 & 0 & 0 & $1(0.7)$ \\
\hline Antidepressant & 0 & 0 & 0 & 1 & 0 & 1 & $1(0.7)$ \\
\hline DMARD & 0 & 0 & 0 & 1 & 0 & 1 & $1(0.7)$ \\
\hline Total & $81(60.5 \%)$ & 37 & 44 & $53(39.5 \%)$ & 30 & 23 & 134 \\
\hline
\end{tabular}

The age groups affected, in descending order, were younger adults (20-39 years; $36.6 \%)$, older adults (40-64 years; 35\%), adolescents (10-19 years; $11.2 \%)$, geriatric patients $(\geq 65$ years, $10.4 \%)$ and children $(0-9$ years, $6.8 \%)$. Sixty study patients $(44.7 \%)$ were managed as inpatients $(\mathrm{M}=28, \mathrm{~F}=32)$ and the rest $74(55.3 \%)$ as out patients $(\mathrm{M}=39 ; \mathrm{F}=35)$. Contribution of CADRs to dermatology IP census was $6 \%$ on an average. Of the total, 60 reactions were serious $(44.7 \%)$ and the rest $(55.3 \%)$ were non serious as per PvPI criteria for classification of drug reactions. 
The drug groups responsible for CADR and their frequency are depicted in Table 1.

Table 2: Common drugs in each drug group.

\begin{tabular}{|c|c|}
\hline Drugs & $\begin{array}{l}\text { Total } \\
\text { (n) }\end{array}$ \\
\hline Anti-convulsants & 33 \\
\hline Phenytoin & 20 \\
\hline Carbamazepine & 13 \\
\hline \multicolumn{2}{|l|}{ NSAIDs } \\
\hline Diclofenac & 30 \\
\hline Paracetamol & 13 \\
\hline Ibuprofen & 7 \\
\hline Nimesulide & 3 \\
\hline Indomethacin & 2 \\
\hline Aspirin & 1 \\
\hline Piroxicam & 1 \\
\hline Metamizole/ dipyrone & 1 \\
\hline Unidentified drugs & 1 \\
\hline Antibiotics & 28 \\
\hline Penicillin group & 15 \\
\hline Cotrimoxazole & 7 \\
\hline Cephalosporins (Cephalexin) & 3 \\
\hline Fluroquinolones (Ciprofloxacin) & 2 \\
\hline Macrolides (Erythromycin) & 1 \\
\hline Alternative system of medicines & 8 \\
\hline Kushtanashini (Psoralea corylifolia linn) & 3 \\
\hline $\begin{array}{l}\text { Vetpalai and swetha kutaja (Wrightia } \\
\text { tinctoria) }\end{array}$ & 2 \\
\hline Neem leaves (Azadirachta indica) & 1 \\
\hline Turmeric (Curcuma longa) & 1 \\
\hline Kuppaimeni leaves (Acalypha indica) & 1 \\
\hline Antiretroviral drugs & 17 \\
\hline $\begin{array}{l}\text { ZLN } \\
\text { (Zidovudine+Lamivudine+Nevirapine) }\end{array}$ & 9 \\
\hline TLE (Tenofovir+ Lamivudine + Efavirenz) & 5 \\
\hline TLN (Tenofovir+Lamivudine + Nevirapine) & 2 \\
\hline SLN (Stavudine+Lamivudine+Nevirapine) & 1 \\
\hline Antifungals & 4 \\
\hline Griseofulvin & 2 \\
\hline Terbinafine & 2 \\
\hline Anti-histamines & 2 \\
\hline Cetirizine & 1 \\
\hline Levocetrizine & 1 \\
\hline Anti-hypertensives (Enalapril) & 1 \\
\hline Antidepressant (Sertraline) & 1 \\
\hline DMARD (Leflunomide) & 1 \\
\hline
\end{tabular}

Benign CADRs were $60.5 \%$ and severe CADRs were $39.5 \%$. There was no significant statistical difference between the proportions of benign $(\mathrm{p}=0.18)$ and severe CADRs $(\mathrm{p}=0.78)$ for NSAIDS, anticonvulsants and antibiotics. The frequency of CADRs among various drugs within each group is depicted in table 2 and the morphological patterns of drug reactions observed are shown in Table 3. There was no significant statistical difference with regards to morphological patterns between male and female patients $(\mathrm{p}=0.09)$.

Table 3: Gender-wise distribution of various morphological patterns of CADRs.

\begin{tabular}{|llll|}
\hline Drug reaction & M & F & Total $(\%)$ \\
\hline Acute exanthem & 19 & 24 & $43(32.2)$ \\
\hline Exfoliative dermatitis & 8 & 12 & $20(14.9)$ \\
\hline TEN & 12 & 7 & $19(14.2)$ \\
\hline FDE & 12 & 4 & $16(11.9)$ \\
\hline SJS & 9 & 3 & $12(8.9)$ \\
\hline Lichenoid dermatitis & 3 & 4 & $7(5.3)$ \\
\hline Acute urticaria & 2 & 4 & $6(4.5)$ \\
\hline Angioedema & 0 & 3 & $3(2.2)$ \\
\hline EMF & 0 & 3 & $3(2.2)$ \\
\hline DRESS & 1 & 1 & $2(1.5)$ \\
\hline $\begin{array}{l}\text { Photo allergic } \\
\text { dermatitis }\end{array}$ & 1 & 1 & $2(1.5)$ \\
\hline SDRIFE & 0 & 1 & $1(0.7)$ \\
\hline Total & 67 & 67 & 134 \\
\hline
\end{tabular}

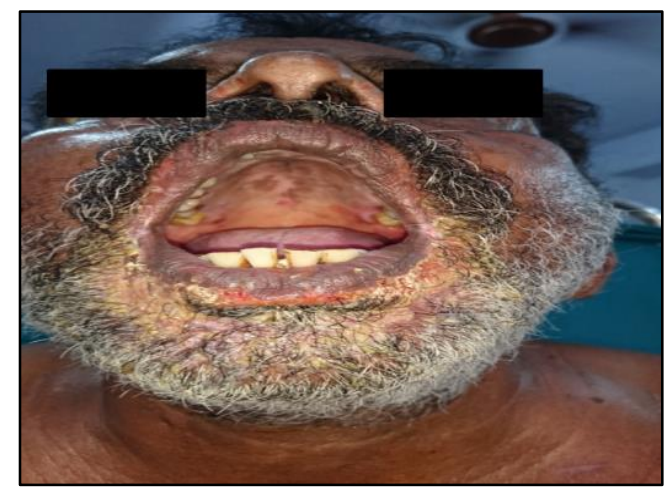

Figure 1: SJS (Carbamazepine) - crusted plaques with erosions over both lips and chin with erosions over hard palate, ala of nose with conjunctival congestion.

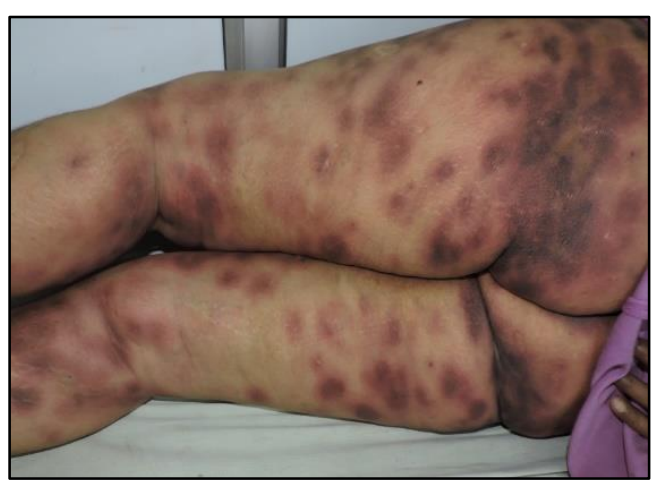

Figure 2: Generalized FDE (Ibuprofen) - multiple well defined oval erythematous to dusky and violaceous patches over both thighs separated by normal skin. 


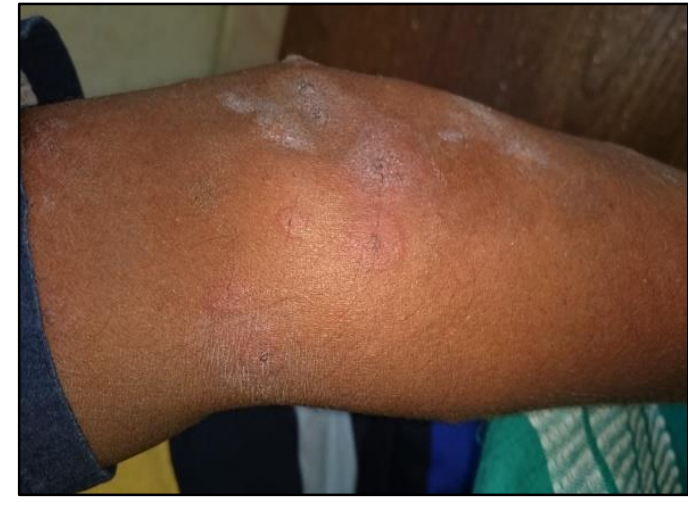

Figure 3: EMF (Diclofenac) - classical target lesions mounting central vesicle over extensor aspect of left elbow.

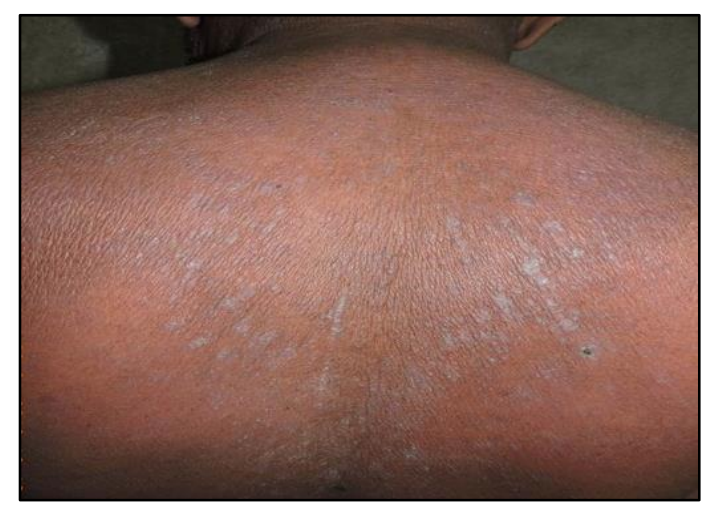

Figure 4: Lichenoid dermatitis (ATT) - multiple illdefined erythematous patches and plaques of varying sizes and shapes with violaceous hue in a background of diffuse erythema over the whole of back.

The common presenting symptoms were itching (84\%), burning sensation (45\%), erythema (33\%), pain (27\%) and pigmentation (18\%). The order of involved body sites were trunk and extremities $(39.5 \%)$, upper limb $(24.3 \%)$, face $(21 \%)$ and other sites $(15.2 \%)$.

The incriminated drugs were mostly $(74.4 \%)$ physician prescribed compared to over the counter (OTC) drugs (25.6\%). Commonly procured OTC drugs were paracetamol, diclofenac, nimesulide, semi-synthetic penicillins and cotrimoxazole with common morphological patterns being FDE, SJS, TEN and acute exanthem due to them. The indications for drug intake were fever $(11.9 \%)$, pain including headache $(17.9 \%)$, seizures $(17.1 \%)$, Upper respiratory tract infections $(9.7 \%)$, HIV (12.6\%), head injury $(3.7 \%)$, tuberculosis (7.4\%) and others (19.7\%). The latency period for the CADRs on an average varied from less than 5 days for angioedema (16 hours) and acute urticaria (30 hours) to more than 20 days for lichenoid dermatitis and exfoliative dermatitis.

A total of $38.1 \%(n=51)$ patients were on polypharmacy (two or more drugs) while $61.9 \%(n=83)$ of patients were on monopharmacy. As shown in table 4, 15.7\% had mild CADR, $53.7 \%$ had moderate and $30.6 \%$ had severe drug reactions based on Hartwig's severity assessment scale with 3 patients belonging to level 7 (2.2\% mortality), one was exfoliative dermatitis due to leflunomide and two were TEN due to phenytoin and carbamazepine each.

\section{DISCUSSION}

CADRs are considered troublesome for patients as well as the treating physicians resulting in significant morbidity in the former. The Pharmacovigilance Programme of India (PvPI) was started by the Government of India on July 14, 2010 with the All India Institute of Medical Sciences (AIIMS), New Delhi as the National Coordination Centre (NCC). The NCC was later shifted to the Indian Pharmacopoeia Commission, Ghaziabad, Uttar Pradesh on April 15, 2011. In 2017, the PvPI in Ghaziabad, became a WHO Collaborating Centre. It was made mandatory to report all suspected adverse drug reactions to PvPI and over time it evolved into a robust well defined system for monitoring and reporting adverse drug reactions and serves several roles such as identification, quantification and documentation of drug related problems which are responsible for drug-related injuries. ${ }^{8}$

Morphological patterns of exanthem can be scarlatiniform, rubelliform or morbilliform. Exfoliative dermatitis is characterized by erythema and scaling involving $90 \%$ or more of body surface area (BSA) which may initially start as exanthem sometimes. SJS/TEN present as an acute eruption of blotchy red spots with associated pain and tenderness, epidermal loss and multiple mucositis with systemic involvement and is classified based on severity of involvement (SJS $<10 \%$ BSA; SJS/TEN overlap: 10$30 \%$ BSA; TEN $>30 \%$ BSA). FDE is characterized by well-defined round to oval erythematous edematous plaque which evolves to become dusky, violaceous, vesicular or bullous lesions. DRESS/DHS is characterized by rash (exanthem or exfoliative dermatitis or rarely TEN), eosinophilia and systemic involvement with or without lymphadenopathy.

Recent studies done on CADRs include studies by Anal Modi et al., Gujarat (2019), Shweta Sharma et al., Kerala (2019), Ankita Agrawal et al., Mumbai (2018) at national level (India) and studies done by Si Xian Wong et al., Singapore (2019) and Chunyou Wang et al., China (2019) at international level, compared in Table 5.,12-15

The observed CADR incidence in this study (2/1000) was almost similar to the studies done in Gujarat (4.5/1000), France (3.6/1000) and Tunisia, North Africa (2.5/1000), but was lower than the studies done in Denmark (13.5/1000) and Malaysia (8.6/1000)..$^{5,6,16-18}$ The incidence was found to be lower in Indian origin patients (3.5/1000) than Malay (8.9/1000) and Chinese (10.7/1000) in the study done in Malaysia. ${ }^{5}$ This reflects the racial and ethnic variations in the incidence of CADRs which needs to be analysed in future studies (Table 5). 
Murthy AB et al. Int J Basic Clin Pharmacol. 2022 Mar;11(2):97-107

Table 4: Hartwig's severity assessment scale.

\begin{tabular}{|c|c|c|c|c|}
\hline Level & Criteria & $\begin{array}{l}\text { Grade } \\
\text { n }(\%)\end{array}$ & $\begin{array}{l}\text { Total numbers } \\
(\%)\end{array}$ & Morphology \\
\hline 1 & The ADR requires no change in the treatment with the suspected drug & \multirow[b]{2}{*}{$\begin{array}{l}\text { Mild } \\
21(15.7 \%)\end{array}$} & $2(1.5 \%)$ & Exanthem -2 \\
\hline 2 & $\begin{array}{l}\text { The ADR requires that the suspected drug be withheld, discontinued or } \\
\text { otherwise changed. No antidote or other treatment is required, and there } \\
\text { is no increase in length of stay }\end{array}$ & & $19(14.2 \%)$ & $\begin{array}{l}\text { Urticaria }-1 \\
\text { Exanthem }-2 \\
\text { FDE }-16\end{array}$ \\
\hline 3 & $\begin{array}{l}\text { The ADR requires that the suspected drug be withheld, discontinued or } \\
\text { otherwise changed and/or an antidote or other treatment is required with } \\
\text { no increase in length of stay }\end{array}$ & \multirow[t]{2}{*}{$\begin{array}{l}\text { Moderate } \\
72(53.7 \%)\end{array}$} & $53(39.5 \%)$ & $\begin{array}{l}\text { SDRIFE - } 1 \\
\text { Photoallergic dermatitis }-2 \\
\text { Lichenoid dermatitis }-2 \\
\text { EMF }-3 \\
\text { SJS }-4 \\
\text { Urticaria - } 5 \\
\text { Exanthem }-36\end{array}$ \\
\hline 4 & $\begin{array}{l}\text { Any level } 3 \text { ADR that increases the length of stay by atleast one day or } \\
\text { the ADR is the reason for admission }\end{array}$ & & $19(14.2 \%)$ & $\begin{array}{l}\text { Exanthem }-3 \\
\text { Angioedema }-3 \\
\text { Lichenoid dermatitis }-5 \\
\text { SJS }-8\end{array}$ \\
\hline 5 & Any level 4 ADR that requires intensive medical care & \multirow{3}{*}{$\begin{array}{l}\text { Severe } \\
41(30.6 \%)\end{array}$} & $38(28.4 \%)$ & $\begin{array}{l}\text { DRESS }-2 \\
\text { TEN }-17 \\
\text { Exfoliative dermatitis }-19\end{array}$ \\
\hline 6 & The ADR causing permanent harm to the patient & & 0 & 0 \\
\hline 7 & The ADR either directly or indirectly leading to the death of the patient & & $3(2.2 \%)$ & $\begin{array}{l}\text { Exfoliative dermatitis }-1 \text { (Leflunomide) } \\
\text { TEN }-2 \text { (phenytoin and carbamazepine) }\end{array}$ \\
\hline
\end{tabular}

Table 5: Comparison of various studies on CADR.

\begin{tabular}{|c|c|c|c|c|c|c|c|}
\hline $\begin{array}{l}\text { Author year state } \\
\text { country }\end{array}$ & $\begin{array}{l}\text { Incidence } \\
\text { sample size }\end{array}$ & $\begin{array}{l}\text { Common age } \\
\text { group in years } \\
(\%)\end{array}$ & Common drug groups & $\begin{array}{l}\text { Common morphological } \\
\text { patterns }\end{array}$ & $\begin{array}{l}\text { Latency period } \\
\text { (shortest and longest) }\end{array}$ & $\begin{array}{l}\text { Polypha } \\
\text { rmacy }\end{array}$ & $\begin{array}{l}\text { Severity assessment } \\
\text { (Hartwig's scale) }\end{array}$ \\
\hline Present study & $\begin{array}{l}2 / 1000 \\
134\end{array}$ & $\begin{array}{l}20-39 \\
(36.6)\end{array}$ & $\begin{array}{l}\text { Anticonvulsants }(24.7 \%) \\
\text { NSAIDS }(22.5 \%) \\
\text { Antibiotics }(20.9 \%)\end{array}$ & $\begin{array}{l}\text { Acute exanthem }(32.2 \%) \\
\text { Exfoliative dermatitis } \\
(14.9 \%) \\
\text { TEN }(14.2 \%) \\
\text { FDE }(11.9 \%) \\
\text { SJS }(8.9 \%)\end{array}$ & $\begin{array}{l}16 \pm 4.5 \text { hours } \\
\text { (angioedema) } \\
53.4 \pm 28.4 \text { days } \\
\text { (lichenoid rash with } \\
\text { exfoliative dermatitis) }\end{array}$ & $37.3 \%$ & $\begin{array}{l}\text { Mild }(15.7 \%) \\
\text { Moderate }(53.7 \%) \\
\text { Severe }(30.6 \%)\end{array}$ \\
\hline
\end{tabular}

Continued. 
Murthy AB et al. Int J Basic Clin Pharmacol. 2022 Mar;11(2):97-107

\begin{tabular}{|c|c|c|c|c|c|c|c|}
\hline $\begin{array}{l}\text { Author year state } \\
\text { country }\end{array}$ & $\begin{array}{l}\text { Incidence } \\
\text { sample size }\end{array}$ & $\begin{array}{l}\text { Common age } \\
\text { group in years } \\
(\%)\end{array}$ & Common drug groups & $\begin{array}{l}\text { Common morphological } \\
\text { patterns }\end{array}$ & $\begin{array}{l}\text { Latency period } \\
\text { (shortest and longest) }\end{array}$ & $\begin{array}{l}\text { Polypha } \\
\text { rmacy }\end{array}$ & $\begin{array}{l}\text { Severity assessment } \\
\text { (Hartwig's scale) }\end{array}$ \\
\hline $\begin{array}{l}\text { Modi et al., } \\
2018 \text { Gujarat } \\
\text { India }\end{array}$ & 538 & $\begin{array}{l}18-35 \\
(46.3)\end{array}$ & $\begin{array}{l}\text { Antimicrobials }(45.7 \%) \\
\text { NSAIDS }(18 \%) \\
\text { Anticonvulsants }(9.7 \%)\end{array}$ & $\begin{array}{l}\text { Acute exanthem }(58.9 \%) \\
\text { Pruritus }(10.6 \%) \\
\text { SJS }(4.8 \%) \\
\text { FDE }(3.5 \%) \\
\text { Urticaria }(3.5 \%)\end{array}$ & $\begin{array}{l}<24 \text { hours (exanthem, } \\
\text { angioedema) 3-6 } \\
\text { months (skin } \\
\text { pigmentation) }\end{array}$ & $7 \%$ & $\begin{array}{l}\text { Mild }-18.58 \% \\
\text { Moderate }-81.2 \% \\
\text { Severe }-0.18 \%\end{array}$ \\
\hline $\begin{array}{l}\text { Sharma et al., } 2019 \\
\text { Kerala }^{13} \text { India }\end{array}$ & 124 & $\begin{array}{l}19-45 \\
(60.5)\end{array}$ & $\begin{array}{l}\text { Antibiotics }-47.6 \% \\
\text { NSAIDS }-16.1 \% \\
\text { Anticonvulsants }-13.7 \%\end{array}$ & $\begin{array}{l}\text { Exanthem }-33 \% \\
\text { Urticaria }-20.1 \% \\
\text { Pruritus }-16.1 \% \\
\text { SJS }-6.5 \%\end{array}$ & $\begin{array}{l}<1 \text { week }(\text { exanthem) } \\
>1 \text { week }(\mathrm{SJS})\end{array}$ & $89.5 \%$ & $\begin{array}{l}\text { Mild }-37.9 \% \\
\text { Moderate }-37.9 \% \\
\text { Severe }-24.2 \%\end{array}$ \\
\hline $\begin{array}{l}\text { Agrawal et al., } \\
2018 \\
\text { Mumbai }^{4} \text { India }\end{array}$ & $\begin{array}{l}6.2 / 1000 \\
160\end{array}$ & $\begin{array}{l}20-40 \\
(46.9)\end{array}$ & $\begin{array}{l}\text { Antimicrobials - } 37.5 \% \\
\text { NSAIDS - } 25 \% \\
\text { Anticonvulsants- } 12.5 \%\end{array}$ & $\begin{array}{l}\text { FDE }-28.7 \% \\
\text { Exanthem }-26.3 \% \\
\text { Urticaria }-20.6 \%\end{array}$ & $\begin{array}{l}10 \text { hours } \\
\text { (angioedema) } \\
15 \text { days (Lichenoid } \\
\text { dermatitis) }\end{array}$ & $71.9 \%$ & $\begin{array}{l}\text { Mild }-70.6 \% \\
\text { Moderate }-16.9 \% \\
\text { Severe }-12.5 \%\end{array}$ \\
\hline $\begin{array}{l}\text { Patel et al., } 2014 \\
\text { systematic review } \\
\text { India }\end{array}$ & $\begin{array}{l}9.22 / 1000 \\
(18 \text { studies } \\
\text { analysed })\end{array}$ & $\begin{array}{l}21-39 \\
(54.4)\end{array}$ & $\begin{array}{l}\text { Antimicrobials }-45.5 \% \\
\text { NSAIDS - } 20.9 \% \\
\text { Anti convulsants - } 14.57 \%\end{array}$ & $\begin{array}{l}\text { Exanthem }-32.4 \% \\
\text { FDE }-20.1 \% \\
\text { Urticaria }-17.5 \%\end{array}$ & $\begin{array}{l}\text { few minutes to } 24 \\
\text { hours (Angioedema) } \\
4 \text { weeks } \\
\text { (Hyperpigmentation) }\end{array}$ & - & $\begin{array}{l}\text { Mild }-11.9 \% \\
\text { Moderate }-53 \% \\
\text { Severe }-35.08 \%\end{array}$ \\
\hline $\begin{array}{l}\text { Thakkar et al., } \\
2017 \text { Gujarat }{ }^{16} \\
\text { India }\end{array}$ & $\begin{array}{l}4.5 / 1000 \\
171\end{array}$ & - & $\begin{array}{l}\text { Antimicrobials }-28.3 \% \\
\text { NSAID - } 20 \% \\
\text { Analgesic and antiepileptic } \\
-12.5 \%\end{array}$ & $\begin{array}{l}\text { Exanthem }-23.9 \% \\
\text { Urticaria }-21.6 \% \\
\text { FDE }-18.1 \% \\
\text { EMF }-5.9 \%\end{array}$ & $\begin{array}{l}0.5 \text { days (angioedema) } \\
210 \text { days (lichenoid } \\
\text { reaction) }\end{array}$ & $54.2 \%$ & - \\
\hline $\begin{array}{l}\text { Pudukadan et al., } \\
2004 \\
\text { Puducherry }{ }^{19} \\
\text { India }\end{array}$ & 90 & $\begin{array}{l}20-39 \\
(52.2)\end{array}$ & $\begin{array}{l}\text { Antimicrobials - } 58.9 \% \\
\text { Anticonvulsants - } 15.5 \% \\
\text { NSAIDS - } 15.5 \%\end{array}$ & $\begin{array}{l}\text { FDE }-31.1 \% \\
\text { Exanthem }-12.2 \% \\
\text { SJS } / \text { TEN }-18.8 \% \\
\text { Urticaria }-7.8\end{array}$ & - & - & - \\
\hline $\begin{array}{l}\text { Wong et al., } \\
2019 \text { Singapore }{ }^{14}\end{array}$ & 104372 & $\begin{array}{c}20-39 \\
(31.1)\end{array}$ & $\begin{array}{l}\text { Antimicrobials }-43.5 \% \\
\text { Antiinflammatory and } \\
\text { antirheumatics }-16.2 \% \\
\text { Analgesics }-9 \%\end{array}$ & $\begin{array}{l}\text { Exanthem }-67.2 \% \\
\text { Angioedema }-13.9 \% \\
\text { Pruritus - } 7.4 \%\end{array}$ & $\begin{array}{l}<24 \text { hours } \\
\text { (angioedema, } \\
\text { urticaria) } \\
69.5 \text { days (alopecia) }\end{array}$ & - & - \\
\hline $\begin{array}{l}\text { Wang et al., } \\
2019 \text { China }^{15}\end{array}$ & 448 & & $\begin{array}{l}\text { Antimicrobials }-21.7 \% \\
\text { Anticonvulsants }-15.8 \% \\
\text { Antipyretic analgesic - } \\
14.7 \%\end{array}$ & $\begin{array}{l}\text { Exanthem }-42 \% \\
\text { EMF }-19.4 \% \\
\text { Urticaria }-10.5 \%\end{array}$ & $\begin{array}{l}1.5 \pm 2.4 \text { days (FDE) } \\
60 \text { days (Lichenoid } \\
\text { dermatitis) }\end{array}$ & - & - \\
\hline $\begin{array}{l}\text { Zaara et al., } \\
2011 \text { Tunisia } \\
\text { North Africa }\end{array}$ & $2.5 / 1000$ & $40-59$ & $\begin{array}{l}\text { Anticonvulsants }-28 \% \\
\text { Antimicrobials }-28 \% \\
\text { NSAIDS - } 15 \%\end{array}$ & $\begin{array}{l}\text { Exanthem }-45 \% \\
\text { AGEP - } 12 \% \\
\text { TEN }-12 \%\end{array}$ & - & - & - \\
\hline
\end{tabular}

Continued. 
Murthy AB et al. Int J Basic Clin Pharmacol. 2022 Mar;11(2):97-107

\begin{tabular}{|c|c|c|c|c|c|c|c|}
\hline $\begin{array}{l}\text { Author year state } \\
\text { country }\end{array}$ & $\begin{array}{l}\text { Incidence } \\
\text { sample size }\end{array}$ & $\begin{array}{l}\text { Common age } \\
\text { group in years } \\
(\%)\end{array}$ & Common drug groups & $\begin{array}{l}\text { Common morphological } \\
\text { patterns }\end{array}$ & $\begin{array}{l}\text { Latency period } \\
\text { (shortest and longest) }\end{array}$ & $\begin{array}{l}\text { Polypha } \\
\text { rmacy }\end{array}$ & $\begin{array}{l}\text { Severity assessment } \\
\text { (Hartwig's scale) }\end{array}$ \\
\hline $\begin{array}{l}\text { Paudel et al., } \\
2017 \\
\text { Nepal }^{21}\end{array}$ & 42 & $\begin{array}{l}26-35 \\
(28.6)\end{array}$ & $\begin{array}{l}\text { Anticonvulsants }-40.5 \% \\
\text { Antimicrobials }-26.2 \% \\
\text { Allopurinol }-9.5 \%\end{array}$ & $\begin{array}{l}\text { SJS }-35.7 \% \\
\text { Exanthem }-16.7 \% \\
\text { Erythrodema }-16.7 \%\end{array}$ & - & - & - \\
\hline $\begin{array}{l}\text { Choon et al., } \\
2012 \\
\text { Malaysia }^{5}\end{array}$ & $\begin{array}{l}8.6 / 1000 \\
\text { Indian origin } \\
\text { patients } \\
(3.5 / 1000) \\
\text { Malay }(8.9 / 1000) \\
\text { Chinese }(10.7 \text { per } \\
1000) \\
362\end{array}$ & $\begin{array}{l}20-59 \\
(67.1)\end{array}$ & $\begin{array}{l}\text { Antibiotics }-40.3 \% \\
\text { Anticonvulsants }-22.4 \% \\
\text { Anti-gout }-13.8 \%\end{array}$ & $\begin{array}{l}\text { Exanthem }-42.3 \% \\
\text { SJS - } 24.3 \% \\
\text { DRESS }-9.4 \% \\
\text { TEN }-5.8 \%\end{array}$ & - & - & - \\
\hline
\end{tabular}

Table 6: Common causative drugs in various morphological patterns of CADRs.

\begin{tabular}{|c|c|c|c|c|c|}
\hline Drugs & Exanthem & $\begin{array}{l}\text { Exfoliative } \\
\text { dermatitis }\end{array}$ & TEN & FDE & SJS \\
\hline NSAIDS & 8 & 5 & 4 & 7 & 3 \\
\hline Anticonvulsants & 10 & 4 & 7 & 1 & 5 \\
\hline Antibiotics & 13 & 6 & 4 & 3 & 2 \\
\hline ART & 4 & 2 & - & 3 & - \\
\hline ATT & 2 & 1 & 1 & - & - \\
\hline Native medicines & 3 & 1 & 3 & - & 1 \\
\hline Antifungal & 2 & - & - & - & - \\
\hline antihistamines & - & - & - & 2 & - \\
\hline Antihypertensives & 1 & - & - & - & - \\
\hline Antidepressant & - & - & - & - & 1 \\
\hline DMARD & - & 1 & - & - & - \\
\hline Total & 43 & 20 & 19 & 16 & 12 \\
\hline
\end{tabular}


Study showed equal sex ratio overall, which indicates that gender does not have effect on occurrence of drug reactions. This was similar to the study done by Tejas et al, (1:0.9) and two more studies done in Gujarat, except from Kerala (1:1.4)..$^{7,12,13,16}$ But we observed slight gender difference for certain drugs and morphology of CADRs.

Mean age of patients affected was 37.9 years $( \pm 16.2)$ which was similar to the study done at JIPMER Puducherry (37.06 years). ${ }^{19}$ Most affected demographic group was young adults comprising $36.6 \%$ of the study population followed by old adults, adolescents, geriatric patients and finally children, with third decade being the most commonly affected which was in accordance with study done in Puducherry and a systematic review from India. ${ }^{7,19}$ This was in contrary to the study done in China (2019) which reported predominance of cases in 4th to 6th decade and another study in France with mean age of 59.7 years. ${ }^{17,20}$ This reflects the age related change in pattern of CADRs across the countries thus exhibiting ethnic variations and it also depends on the co-morbid illnesses for which they may be taking different drugs. Hence, according to this study it is well evident that most of the drug reactions are in the younger age group coinciding with high Indian population in this age group who are also the active working population in the community.

As depicted in Table 1, common group of drugs responsible for CADR were anticonvulsants followed by NSAIDS and antibiotics. This was similar to studies conducted by Paudel et al, (Nepal) and Ines Zaara et al, (Tunisia, North Africa). ${ }^{18,21}$ On the contrary, most of the studies done in different parts of India and also in other countries reported antimicrobials to be the commonest drug followed by NSAIDS and anticonvulsants (Table 5). ${ }^{7,12-16,19}$ High use of antibiotics and analgesics procured OTC could be the reasons. The study duration of these studies shown that there is not much change in the above trend over the past two decades. Differences in the prevalence of epilepsy and other neurological disorders and road safety measures in different countries could account for varied results in various countries.

Among the CADRs caused by anticonvulsants, common drugs implicated were phenytoin followed by carbamazepine of which $51.5 \%$ were severe with TEN, SJS (Figure 1), exfoliative dermatitis and DRESS and $48.5 \%$ were benign CADRs with exanthem, lichenoid dermatitis and urticaria. Anticonvulsants showed high incidence of severe CADRs, a possible reason could be the strong association of South Asians including Indians with the HLA - B*1502 allele which resulted in the FDA's decision to recommend HLA testing for all Asians. ${ }^{22,23}$ In contrary, in a similar study done in Korea, exanthem and urticaria accounted for $91.8 \%$ of cases followed by DRESS, and the drugs implicated, in order, were lamotrigine followed by valproic acid and carbamazepine. $^{24}$ Thus drug priority and genomic susceptibility seem to be the determining factors of severe CADRs between the ethnic groups.
Of the CADRs caused by NSAIDS majority were benign CADRs (60\%) commonly exanthem, FDE (Figure 2), photoallergic dermatitis and the rest $(40 \%)$ were severe CADRs commonly exfoliative dermatitis, TEN, SJS and EMF (Figure 3). Whereas in a Thailand study, most common drug implicated was ibuprofen and the most common pattern being angioedema/urticaria. ${ }^{25}$ In our country still people are able to procure banned drugs like nimesulide as OTC drugs which needs political commitments to eradicate such practices.

Among the CADRs caused by antibiotics $57.1 \%$ were benign CADRs commonly exanthem, FDE, angioedema and urticaria and $42.9 \%$ were severe CADRs commonly exfoliative dermatitis, TEN and SJS. But in a systematic review done in India, describing CADRs from 1995 to 2013, sulpha drugs were the most common antibiotics and the drug reactions observed mainly were exanthem and urticaria, whereas fluoroquinolones (FDE) and beta lactams (acute exanthem) were the most common antibiotics in studies done later in Gujarat and Mumbai respectively. ${ }^{4,7,16}$ This reflects the regional change in preference as well as prescription of antibiotics over the decades.

Among the CADRs caused by ART, majority were caused by ZLN followed by TLE, TLN and SLN of which $88.2 \%$ were benign CADRs, commonly exanthem and FDE and the rest $(11.8 \%)$ were severe CADRs like EMF, TEN and exfoliative dermatitis especially with nevirapine combinations. Similar to this study, in Maharashtra, a study has reported that the most common drug combination responsible was ZLN. ${ }^{26}$ Because the ART drugs are usually available in fixed dose combinations, it imposes great risk on the patient for developing CADRs and management also becomes difficult as identification of a specific drug is a challenge.

Of the CADRs caused by ATT $(n=7)$, drugs responsible were combinations of isoniazid, rifampicin, pyrazinamide, ethambutol, streptomycin, levofloxacin, moxifloxacin and cycloserine of which only 2 cases were severe CADRs (lichenoid rash with exfoliative dermatitis) and rest of the cases were benign CADRs commonly exanthem, FDE, photodermatitis and lichenoid dermatitis (Figure 4). Drug re-challenge was done in two cases, and the notorious drug was identified as isoniazid and the rest resolved with use of short course of oral steroids and topicals in spite of continuing ATT as drug withdrawal and re-challenge were difficult in MDR and XDR TB regimens considering the disease nature. In a study done in Himachal Pradesh over 3 years, with a sample size 40 (36 were re-challenged with drugs), ethambutol (45\%) was the most common drug responsible with exanthem being the commonest morphological pattern described. Identification of the notorious drug was made possible by drug rechallenge as majority were on category 1 ATT $(77.5 \%) .{ }^{27}$

Among the CADRs caused by native and siddha medicines, the common drugs implicated were 
kushtanashini (Psoralea corylifolia linn) used for vitiligo and skin rashes, vetpalai and swetha kutaja (Wrightia tinctoria) for psoriasis, neem leaves (Azadirachta Indica), turmeric (Curcuma longa), kuppaimeni leaves(Acalypha Indica) of which $62.5 \%$ were severe CADRs commonly exfoliative dermatitis, TEN and SJS and the rest were benign CADRs commonly exanthem, lichenoid dermatitis, angioedema, urticaria and generalized pruritus with excoriations. Usage of native medicines which is a very common practice in our region, also applied topically often, produces contact dermatitis and hence morphology of reactions overlap and the actual pattern is obscured in many cases. Acalypha Indica contains phytochemicals like tannins, flavonoids, alkaloids, saponins and terpenoids responsible for CADRs leading to cell apoptosis by several mechanisms. ${ }^{28,29}$ There are not many studies clearly describing CADRs to native medicines. Hence, well planned scientific studies in this aspect are the need of the hour.

The morphologies of CADRs with their common causative drugs are depicted in Table 6, with most common being acute exanthem followed by exfoliative dermatitis and TEN. There are regional and ethnic variations in the frequency of morphological patterns between north and south India and also across countries, even though exanthem is the commonest among all, which needs to be further explored (Table 5).

In this study, the shortest mean latency period was for acute angioedema (16 hours) and longest was for lichenoid dermatitis $(53.4 \pm 28.4$ days $)$ which was similar to the study conducted in Mumbai (Table 5). ${ }^{4}$ Though latency period is given as mean $\pm \mathrm{SD}$, most of the urticaria and angioedema occurred within hours and few FDE cases occurred within 1 to 2 days. The causative drugs were mostly (74.4\%) physician prescribed compared to over the counter (OTC) drugs $(25.6 \%)$ with the common drug reaction pattern observed in OTC drug intake being FDE, SJS, and acute exanthem, which was similar to the study done by Abanti Saha et al. from Kolkata. ${ }^{30}$

In current study, benign CADRs $(60.5 \%)$ were more common than severe $(39.5 \%)$ which is similar to the observations in most studies (Table 5) except one study from Gujarat where severe CADRs were commoner. ${ }^{31}$ Most common cause of benign CADR was NSAIDS $(22.2 \%)$ and severe CADR was anticonvulsants (32\%). Though there was an apparent gender difference between benign and severe CADRs due to NSAIDS, anticonvulsants and antibiotics, there was no significant statistical difference.

According to Hartwig's severity assessment scale, majority of the CADRs were moderate in severity $(53.7 \%)$ followed by severe $(30.6 \%)$ and mild (15.7\%) (Table 4). It is similar to many Indian studies in systematic review where moderate severity ranged from $37.9 \%$ to $81.6 \%$ except a study from Mumbai (mild - 70.6) (Table 5). This information is missing in many international studies.
CADRs from level 4 onwards needed admission and observation. Level 7 represented death due to CADRs which included 3 patients $(2.2 \%)$, one was recalcitrant exfoliative dermatitis due to leflunomide and two were TEN due to phenytoin and carbamazepine. This was concurrent with a systematic review done in India (1.71\%) but higher compared to the study done in Singapore $(0.1 \%)$, with major causes of mortality being similar (TEN followed by exfoliative dermatitis). ${ }^{7,14}$ It is to be noted that there are no adequate data regarding severity among global studies. Non serious CADRs (55.3\%) were managed as OP and serious reactions (44.7\%) needed admissions as per PvPI criteria. In a study done in Gujarat, $80 \%$ were nonserious and the rest $(20 \%)$ were serious. ${ }^{32}$

The definitions for polypharmacy as given by different studies ranged from two or more to 11 or more medicines. ${ }^{33}$ More than one third of patients had taken multiple drugs in this study, which was similar to a study from Gujarat which also reported polypharmacy in $35.3 \%$ of cases, and from Vietnam in 40\%. ${ }^{16,34}$ But it differed from the study done in Mumbai in which $71.9 \%$ had received polypharmacy. ${ }^{4}$ Most common drugs involved in polypharmacy were penicillins and paracetamol for fever, ART drugs (tenofovir, lamivudine, efavirenz) and ATT drugs (isoniazid, rifampicin, pyrazinamide, ethambutol and streptomycin) in this study. The common morphological patterns of CADRs observed in these were acute exanthem, TEN, exfoliative dermatitis and lichenoid dermatitis which were seen even in younger population due to infections like TB and HIV. Though there are many people on multiple combinations of drugs for diabetes and hypertension, reports of CADRs seem to be less, which needs special attention and exploration.

The limitations of this study were, though drug rechallenge was done in 2 cases in our study, it could have also been done in all cases. The non-inclusion of WHO causality assessment, Schumock and Thornton's criteria for preventability of CADR's were the other limitations which can be considered in future large scale multicentric studies.

\section{CONCLUSION}

Exploring ethnic variability predisposing to development of drug reactions and mandatory HLA screening before prescribing anticonvulsants can reduce drug reactions. Awareness must be brought among people about harmful effects of use of OTC drugs and schedule " $\mathrm{H}$ " drugs. It is essential for physicians to update their knowledge regularly, to assess benefits and risk ratio and to take therapeutic decisions accordingly. It also requires stringent drug policy measures and scrupulous adoption of the rules and regulations which requires commitment from all stakeholders viz. policy makers down to consumers. Drug reactions due to native and alternate system medicines need special attention, and are commoner than expected or believed to be, which is highlighted in this study. Hartwig's severity assessment scale has proved to be an 
efficient tool for categorising the CADR's and predicting their expected outcome.

Funding: No funding sources

Conflict of interest: None declared

Ethical approval: The study was approved by the Institutional Ethics Committee

\section{REFERENCES}

1. Brar BK, Kaur J, Kumar S, Sethi N, Kumar R. Cutaneous adverse drug reactions profile in a tertiary care hospital in North India. J Pak Assoc Dermatol. 2017;27(2):158-63.

2. Bigby M. Rates of cutaneous reactions to drugs. Arch Dermatol. 2001;137(6):765-70.

3. Noel MV, Sushma M, Guido S. Cutaneous adverse drug reactions in hospitalized patients in a tertiary care center. Indian J Pharmacol. 2004;36(5):292-5.

4. Agrawal A, Ghate S, Gupta AK, Dhurat R. Clinical spectrum of cutaneous adverse drug reactions. Indian J Drugs Dermatol. 2018;4:61-6.

5. Choon SE, Lai NM. An epidemiological and clinical analysis of cutaneous adverse drug reactions seen in a tertiary hospital in Johor, Malaysia. Indian J Dermatol Venereol Leprol. 2012;78(6):734-9.

6. Borch JE, Andersen KE, Bindslev-Jensen C. Cutaneous adverse drug reactions seen at a university hospital department of dermatology. Acta Derm Venereol. 2006;86(6):523-7.

7. Patel TK, Thakkar SH, Sharma D. Cutaneous adverse drug reactions in Indian population: A systematic review. Indian Dermatol Online J. 2014;5(2):S76-86.

8. Kumar DA, Reddenna L, Basha SA. Pharmacovigilance Programme of India. Innov Pharm. 2015;6(1):13.

9. Hartwig SC, Siegel J, Schneider PJ. Preventability and severity assessment in reporting adverse drug reactions. Am J Hosp Pharm. 1992;49(9):2229-32.

10. Brockow K, Ardern-Jones MR, Mockenhaupt M, Aberer W, Barbaud A, Caubet JC, et al. EAACI position paper on how to classify cutaneous manifestations of drug hypersensitivity. Allergy. 2019;74(1):14-27.

11. CFR - Code of Federal Regulations Title 21. Available at: https://www.accessdata.fda.gov/scripts/ cdrh/cfdocs/cfcfr/cfrsearch.cfm?fr=312.32. Accessed on 9 October 2020.

12. Modi A, Desai M, Shah S, Shah B. Analysis of Cutaneous Adverse Drug Reactions Reported at the Regional ADR Monitoring Center. Indian J Dermatol. 2019;64(3):250.

13. Sharma S, Jayakumar D, Palappallil DS. Pharmacovigilance of cutaneous adverse drug reactions among patients attending dermatology department at a tertiary care hospital. Indian Dermatol Online J. 2019;10(5):547-54.

14. Wong SX, Tham MY, Goh CL, Cheong HH, Chan SY. Spontaneous cutaneous adverse drug reaction reports-
An analysis of a 10-year dataset in Singapore. Pharmacol Res Perspect. 2019;7(2):e00469.

15. Wang C, Wang P, Ge L, Zhao X, Song Z, You Y. Cutaneous adverse drug reactions in Southwest China: Retrospective analysis of 448 cases of inpatients in a dermatology ward from 2010 to 2017. Australas J Dermatol. 2019;60(4):e364-5.

16. Thakkar S, Patel TK, Vahora R, Bhabhor P, Patel R. Cutaneous adverse drug reactions in a tertiary care teaching hospital in India: An intensive monitoring study. Indian J Dermatol. 2017;62(6):618.

17. Fiszenson-Albala F, Auzerie V, Mahe E, Farinotti R, Durand-Stocco C, Crickx B, et al. A 6-month prospective survey of cutaneous drug reactions in a hospital setting. Br J Dermatol. 2003;149(5):1018-22.

18. Zaraa I, Jones M, Trojjet S, Rouhou R, El Euch D, Mokni $M$ et al. Severe adverse cutaneous drug eruptions: epidemiological and clinical features. Int J Dermatol. 2011;50(7):877-80.

19. DevinderMohan T. Adverse cutaneous drug reactions: Clinical pattern and causative agents in a tertiary care center in South India. Indian J Dermatol Venereol Leprol. 2004;70(1):20.

20. Zhao J, Hu L, Zhang L, Zhou M, Gao L, Cheng L. Causative drugs for drug-induced cutaneous reactions in central China: a 608-case analysis. An Bras Dermatol. 2019;94(6):664-70.

21. Paudel U, Parajuli S, Pokhrel D. Patterns and Outcomes of Cutaneous Adverse Drug Reactions in a Hospital Based Study. Nepal J Dermatol Venereol Leprol. 2017;15:44.

22. Meenakshi B, Nirmaladevi P, Radha M, Rahuman MB, Shantaraman K. Profile of cutaneous adverse drug reactions of carbamazepine. Int $\mathrm{J}$ Basic Clin Pharmacol. 2017;6(12):2876-80.

23. Dodiuk-Gad RP, Chung WH, Yang CH, Lu CW, Hui RCY, Shear NH. The 8th International Congress on Cutaneous Adverse Drug Reactions, Taiwan, 2013: focus on severe cutaneous adverse reactions. Drug Saf. 2014;37(6):459-64.

24. Kim H, Kim D, Bae E, Kim D. Adverse Skin Reactions with Antiepileptic Drugs Using Korea Adverse Event Reporting System Database, 20082017. Journal of Korean Medical Science. 2020;35(4).

25. Kasemsarn P, Kulthanan K, Tuchinda P, Dhana N, Jongjarearnprasert $\mathrm{K}$. Cutaneous reactions to nonsteroidal anti-inflammatory drugs. J Drugs Dermatol JDD. 2011;10(10):1160-7.

26. Patil PT, Pawar MP, Halasawadekar NR, Shinde MP, Kumbhar AV, Rathod MS. Current pattern of adverse drug reactions to anti-retroviral therapy in an antiretroviral therapy centre attached to a government medical college of Maharashtra, India: a retrospective study. Int J Basic Clin Pharmacol. 2016;5(6):2438-43.

27. Sharma RK, Verma GK, Tegta GR, Sood S, Rattan R, Gupta M. Spectrum of cutaneous adverse drug reactions to anti-tubercular drugs and safe therapy after re-challenge - A retrospective study. Indian Dermatol Online J. 2020;11(2):177. 
28. Banala RR, Vemuri SK, Reddy AV, Subbaiah GPV. Aqueous extract of Acalypha indica leaves for the treatment of Psoriasis: In-vitro studies. Int J Bioassays. 2017;6(04):5360.

29. Sundarrajan S, Lulu S, Arumugam M. Deciphering the mechanism of action of wrightia tinctoria for psoriasis based on systems pharmacology approach. J Altern Complement Med N Y N. 2017;23(11):866-78.

30. Saha A, Das NK, Hazra A, Gharami RC, Chowdhury $\mathrm{SN}$, Datta PK. Cutaneous adverse drug reaction profile in a tertiary care out patient setting in Eastern India. Indian J Pharmacol. 2012;44(6):792.

31. Tejashwani, Patel D, Bhuptani N. An observational study of cutaneous adverse drug reactions in tertiary hospital. Int J Res Dermatol. 2018;4(2):254-8.

32. Bhabhor PH, Patel TK, Vahora R, Patel PB, Desai N. Adverse drug reactions in a tertiary care teaching hospital in India: analysis of spontaneously reported cases. Int J Basic Clin Pharmacol. 2017;3(6):1078-85.

33. Masnoon N, Shakib S, Kalisch-Ellett L, Caughey G. What is polypharmacy? A systematic review of definitions. BMC Geriatrics. 2017;17(1).

34. Zhang C, Van DN, Hieu C, Craig T. Drug-induced severe cutaneous adverse reactions: Determine the cause and prevention. Ann Allergy Asthma Immunol Off Publ Am Coll Allergy Asthma Immunol. 2019;123(5):483-7.

Cite this article as: Murthy $\mathrm{AB}$, Amuthavalli $\mathrm{K}$, Nirmaladevi P, Meenakshi B. Analysis of cutaneous adverse drug reactions in a tertiary care hospital in South Tamil Nadu. Int J Basic Clin Pharmacol 2022;11:97-107. 